\title{
Body volume in ground beetles (Carabidae) reflects biotope disturbance
}

\author{
Vladimír Langraf $^{1^{*}}$, Kornélia Petrovičová ${ }^{1}$, Stanislav David $^{1}$, Monika Ábelová ${ }^{1}$, Janka Schlarmannová $^{2}$
}

\author{
${ }^{1}$ Department of Ecology and Environmental Sciences, Faculty of Natural Sciences Constantine the Philosopher \\ University in Nitra, Tr. A. Hlinku 1, Nitra, 94974 Slovak Republic \\ ${ }^{2}$ Department of Zoology and Anthropology, Faculty of Natural Sciences, Constantine the Philosopher University \\ in Nitra, Tr. A. Hlinku 1, 94974 Nitra, Slovak Republic
}

\begin{abstract}
Langraf, V., Petrovičová, K., David, S., Ábelová, M., Schlarmannová, J., 2017. Body volume in ground beetles (Carabidae) reflects biotope disturbance. Folia Oecologica, 44: 114-120.

Changes in body size of living organisms can indicate changes in environmental quality. The family Carabidae is frequently used as an indicator of environmental status. We collected ground beetles in 9 Slovakian localities (in the Veporské vrchy Mts and the Juhoslovenská kotlina Basin) of various levels of disturbance, and evaluated the volume of individuals. The lowest average body volumes of individual were found for an intensively grazed pasture (locality 5) and a nitrophilous waterside vegetation (locality 6) $\left(1,298 \mathrm{~mm}^{3}-4,648\right.$ $\mathrm{mm}^{3}$ ) with predominantly macropterous species. We have confirmed the significantly higher average biovolume value of individual Carabidae in less disturbed habitats: a Picea abies plantation (locality 1), a Carpathian oak-hornbeam forest (locality 4) and a Carpathian turkey oak forest (locality 7) (from 9,837 $\mathrm{mm}^{3}$ to $13,038 \mathrm{~mm}^{3}$ ), where apterous and brachypterous species dominated.
\end{abstract}

\section{Keywords}

biovolume, Carabidae, indicator, Slovakia

\section{Introduction}

Environmental quality, resource availability, and interspecific interactions all influence metabolic activity, generation time, reproductive rate, and also the body size of organisms (WeST et al., 1997). Depending on body size, we can also predict if an organism is a potential predator or prey (PETERs, 1983). Changes in the body size and an individual species distribution across a certain space are parameters that indicate the degree of environmental burden (McGeOCH, 1998). Relationships between the species structure of animal communities and the body size were also studied in connection with their use as bioindicators in a long-term anthropogenic intervention (BROwN, 1995). The family Carabidae is suitable for such calculations because the ecological characteristics of the species are well known (LöveI and SunDERLAND, 1996) and these can be used for bioindication. RouABAH et al. (2015) analyzed the influence of vegetation structure on the diversity, and spatial distribution of ground beetles in correlation with their body size. They confirmed that big-bodied species achieve high population densities in forests, while small species prefer species-rich meadow vegetation. ŠUSTEK (1987) found that average body size of the ground beetles decreased in areas under intensive anthropogenic disturbance. LöVEI and MAGURA (2006) reported that average body size in predatory carabids decreased close

*Corresponding author: e-mail: vladimir.langraf@ukf.sk

(C) 2017 Authors. This is an open access article under the CC BY-NC-ND license (http://creativecommons.org/licenses/by-nc-nd/3.0/) 
to an industrial area, but not in slightly polluted areas. Szyszko (1983) found that the average size of ground beetles increased with decreasing disturbance in Polish pine forests, and concluded that "the decrease of environmental disturbance allows a larger than average body size". MAGURA et al. (2006) analyzed differences in the ground beetle body size distribution influenced by urbanization along a forest-urban park urbanisation gradient. They confirmed the presence of individuals of various species with larger body size in rural rather than in urban or suburban areas. BRAUN et al. (2004) claimed that the average species size increased with decreasing environmental pollution at a former chemical factory site in Germany. They used the term biovolume, calculated from morphometric parameters of individuals (body length, thickness and width) to characterise ground beetle body size (volume). The family Carabidae is suitable for such calculations because of their relatively large body size. MAJZLAN and FrANTzoví (1994) compared biovolume values of male vs. female carabids. In most cases, females were bigger than males (although not confirmed statistically). Only 3 ground beetles species (Panagaeus crux-major, Pterostichus diligens and Harpalus schaubergerianus) have larger males than females. The biggest differences between the sexes exist in the genus Carabus. In their study, MAJZLAN and Frantzoví confirmed that the species is of bigger volume display major value differences of biovolume between the sexes. MAJZLAN and BAŤALÍK (1997) also confirmed this fact. TeIJI et al. (2000) have analyzed 15 beetle species of the genus Carabus. The average female was bigger than the average male, except for the Carabus uenoi.

Marcoptery or brachyptery within ground beetles are related to ecosystem stability, mostly via habitat structure and vegetation type (SoNOMI et al., 2014). Larger average body size is related to the occurrence of apterous and brachypterous ground beetles (MAJZLAN and Frantzoví, 1994). On the contrary, the smaller average body size indicates the presence of macropterous species in the biotope. Brachypterous and apterous ground beetles are unable to fly, so their dispersal power is lower, and they colonise new biotopes with more difficulties. Macropterous forms of ground beetles can more easily occupy new biotopes, and consequently, sudden and substantial changes in biotopes influence apterous and brachypterous species more profoundly. Species living in stable ecosystems lose their flight ability, but species living in cyclical changeable ecosystems still retain their flight ability (PORHAJÁŠové and Šustek, 2011). The predominance of apterous and brachpterous species indicates a higher degree of environmental stability, and the presence of macropterous species indicates less stable environmental conditions.

The aim of this paper is to evaluate the body size changes (biovolume) of ground beetles influenced by various intensities of anthropogenic activities in nine biotopes of Slovakia, in the Veporské vrchy Mountains and the Juhoslovenská kotlina Basin. We focused on evaluating the following hypotheses: (i) there is no difference in the average value $\mathrm{Bv}$ for males and females, (i) the average body size value $(\mathrm{Bv})$ of ground beetles decreases from less disturbed anthropogenic biotopes to more disturbed ones.

\section{Materials and methods}

The study areas are located in the southern part of Slovakia in the geomorphological units of the Veporské vrchy Mountains and the Juhoslovenská kotlina Basin (Table 1).

Ground beetles were collected from April to October 2015, in 9 localities representing 7 types of biotopes, classified according to RUŽIČKová et al. (1996). We used pitfall traps $(750 \mathrm{ml})$ and Möricke traps (1,500 $\mathrm{ml}$ ) which are yellow and attract insects (NovéK et al., 1969). The traps were arranged in 5 lines in each biotope. The distance between the individual traps was 10 $\mathrm{m}$ from each other and there were 10 traps per a line. As a killing agent, we used 4\% saline solution. The traps were checked and emptied at regular two-week intervals. The collected material was sorted in the laboratory, and carabids were identified to species using the nomenclature and keys according to HŮRKA (1996). We measured the following morphometric characters on each individual according to BRAUN et al. (2004): (i) body length in $\mathrm{mm}$, as the dorsal length between the upper lip (labrum) and the terminal part of elytra, (ii) the body width ( $\mathrm{mm}$ ) as the length between the edges at the maximum width of the elytra, and (iii) body thickness $(\mathrm{mm})$ as the maximum dorsoventral thickness on the left side of the body. To minimize the measuring error, each parameter was measured three times, and the arithmetic average was used. On the grounds of measured morphometric features, the volume of each individual or biovolume $(\mathrm{Bv})$ was calculated as:

$$
\mathrm{Bv}=(\mathrm{h}+\check{\mathrm{s}} / 2)^{2} . \mathrm{D} \cdot \pi,
$$

where $\mathrm{h}$ is individual thickness, $\breve{\mathrm{s}}$ is individual width, $\mathrm{D}$ is individual length, (MaJzlan and Frantzoví 1995). Flight ability was assigned as in HŮRKA (1996).

The resulting $\mathrm{Bv}$ values are given in $\mathrm{mm}^{3}$. The results indicate the average $\mathrm{Bv}$ value of the subject on the habitat. The data analysis sample represents the Bv $\left(\mathrm{mm}^{3}\right)$ values of individuals captured into the pitfall traps and Möricke traps at each habitat.

We used the Statistica Cz. Ver. 7.0 (STATSOFT, Inc., 2004) program for statistical analysis of morphometric signs and biovolume. The analysis was focused on:

- the morphometry and biovolume were analyzed by descriptive statistics

- testing normality of data distribution

- testing deviations to average values by gender for selected species 
Table 1. Location data of the study localities and their biotope characteristics

\begin{tabular}{|c|c|c|c|c|}
\hline Locality & Municipality & $\begin{array}{c}\text { Altitude } \\
(\mathrm{m} \text { asl })\end{array}$ & Biotope & Geographic coordinates \\
\hline \multicolumn{5}{|c|}{ Veporské vrchy Mts } \\
\hline Lichovo & Utekáč & 518 & $\begin{array}{c}\text { Picea abies plantation } \\
\text { forest }\end{array}$ & $\begin{array}{l}48^{\circ} 36^{\prime} 27^{\prime \prime} \mathrm{N} \\
19^{\circ} 48^{\prime} 23^{\prime \prime} \mathrm{E}\end{array}$ \\
\hline Lichovo & Utekáč & 556 & Pasture & $\begin{array}{l}48^{\circ} 36^{\prime} 30^{\prime \prime} \mathrm{N} \\
19^{\circ} 48^{\prime} 35^{\prime \prime} \mathrm{E}\end{array}$ \\
\hline Farkaška & Utekáč & 446 & $\begin{array}{c}\text { Nitrophilous waterside } \\
\text { vegetation }\end{array}$ & $\begin{array}{l}48^{\circ} 36^{\prime} 34^{\prime \prime} \mathrm{S} \\
19^{\circ} 47^{\prime} 52^{\prime \prime} \mathrm{N}\end{array}$ \\
\hline \multicolumn{5}{|c|}{ Juhoslovenská kotlina Basin } \\
\hline Kúpna hora & Poltár & 300 & $\begin{array}{l}\text { Carpathian oak- } \\
\text { hornbeam forest }\end{array}$ & $\begin{array}{l}48^{\circ} 26^{\prime} 09^{\prime \prime} \mathrm{N} \\
19^{\circ} 49^{\prime} 27^{\prime \prime} \mathrm{E}\end{array}$ \\
\hline Prievranka & Poltár & 272 & Pasture & $\begin{array}{l}48^{\circ} 25^{\prime} 52^{\prime \prime} \mathrm{N} \\
19^{\circ} 49^{\prime} 08^{\prime \prime} \mathrm{E}\end{array}$ \\
\hline Pažit’ & Poltár & 218 & $\begin{array}{c}\text { Nitrophilous waterside } \\
\text { vegetation }\end{array}$ & $\begin{array}{l}48^{\circ} 25^{\prime} 41^{\prime \prime} \mathrm{N} \\
19^{\circ} 46^{\prime} 35^{\prime \prime} \mathrm{E}\end{array}$ \\
\hline Pri Ladove & Lučenec & 258 & $\begin{array}{c}\text { Carpathian turkey oak } \\
\text { forest }\end{array}$ & $\begin{array}{l}48^{\circ} 19^{\prime} 08^{\prime \prime} \mathrm{N} \\
19^{\circ} 37^{\prime} 48^{\prime \prime} \mathrm{E}\end{array}$ \\
\hline Zajačie brehy & Lučenec & 208 & Fallow field & $\begin{array}{c}48^{\circ} 19^{\prime} 017^{\prime \prime} \mathrm{N} \\
19^{\circ} 39^{\prime} 05^{\prime \prime} \mathrm{E}\end{array}$ \\
\hline Ladovo & Lučenec & 207 & $\begin{array}{c}\text { Nitrophilous waterside } \\
\text { vegetation }\end{array}$ & $\begin{array}{l}48^{\circ} 20^{\prime} 12^{\prime \prime} \mathrm{N} \\
19^{\circ} 37^{\prime} 06^{\prime \prime} \mathrm{E}\end{array}$ \\
\hline
\end{tabular}

We used the Lilliefors test, Shapiro-Wilk's W test for testing normality in Bv distribution and morphometric parameters, respectively. We analyzed biotopic influence on $\mathrm{Bv}$ for both sexes by one-way ANOVA. Testing differences in $\mathrm{Bv}$ between sexes was made by a non-parametric Kruskal-Wallis test.

\section{Results}

We collected 1,873 individuals (882 males, 991 females) belonging to 44 species (see Appendix). The highest abundance was found in the habitat Culture of Picea abies (466 individuals collected), while the lowest (95 adults) in pasture. Nitrophilous waterside vegetation was the most species-rich habitat (21 species) and the lowest number of species was collected in Carpathian oak-hornbeam forest (11 species).

All Bv values were normally distributed. The lowest average $\mathrm{Bv}$ value of individuals was recorded in the pasture (locality 5), and the highest in the biotope of Carpathian oak-hornbeam forest (locality 4) (Table 2). The average values were close to the median values for the biotopes of Picea abies plantation (locality 1), pasture (locality 2), Carpathian turkey oak forest (locality 7), fallow field (locality 8) and nitrophilous waterside vegetation (locality 9).

The parametric ANOVA indicated significant $(\mathrm{p}=$ 0.00 ) difference in the average $\mathrm{Bv}$ values among the localities (Fig. 1). The biotopes with the lowest average $\mathrm{Bv}$ values were also the ones with presence of small macropterous species. On the other hand, biotopes with a higher average Bv value had mostly apterous and brachypterous species.

Biotopes pasture (locality 2) and nitrophilous waterside vegetation (locality 9) show an approximately even number of apterous, brachypterous and macropterous species. In the forested biotopes and nitrophilous waterside vegetation (locality 3 ), apterous species prevailed, which may indicate greater ecological stability. We found more macropterous species in the biotopes with intensive agricultural land use.

During the evaluation, we were also comparing the $\mathrm{Bv}$ values of males and females of species with at least 35 individuals of each sex: Abax parallelepipedus, Carabus coriaceus, C. glabratus, C. hortensis, C. violaceus and Harpalus affinis (Table 3).

Non-normality was detected for females of Carabus glabratus, C. hortensis and for males Carabus coriaceus, C. hortensis, and Harpalus affinis. Statistically significantly different $\mathrm{Bv}$ values were reported for $\mathrm{Abax}$ parallelepipedus Carabus coriaceus, C. glabratus and C. violaceus but not for Carabus hortensis $(\mathrm{p}=0.12)$ and Harpalus affinis $(\mathrm{p}=0.54)$.

\section{Discussion}

Through our research, we evaluated the anthropogenic (developed agriculture) impact on carabid beetles. By $\mathrm{Bv}$ and flight abilities, we achieved a more comprehensive bioindication evaluation of 9 localities, representing 6 types of biotopes. The species were divided on the basis of flight ability according to HŮRKA (1996), 


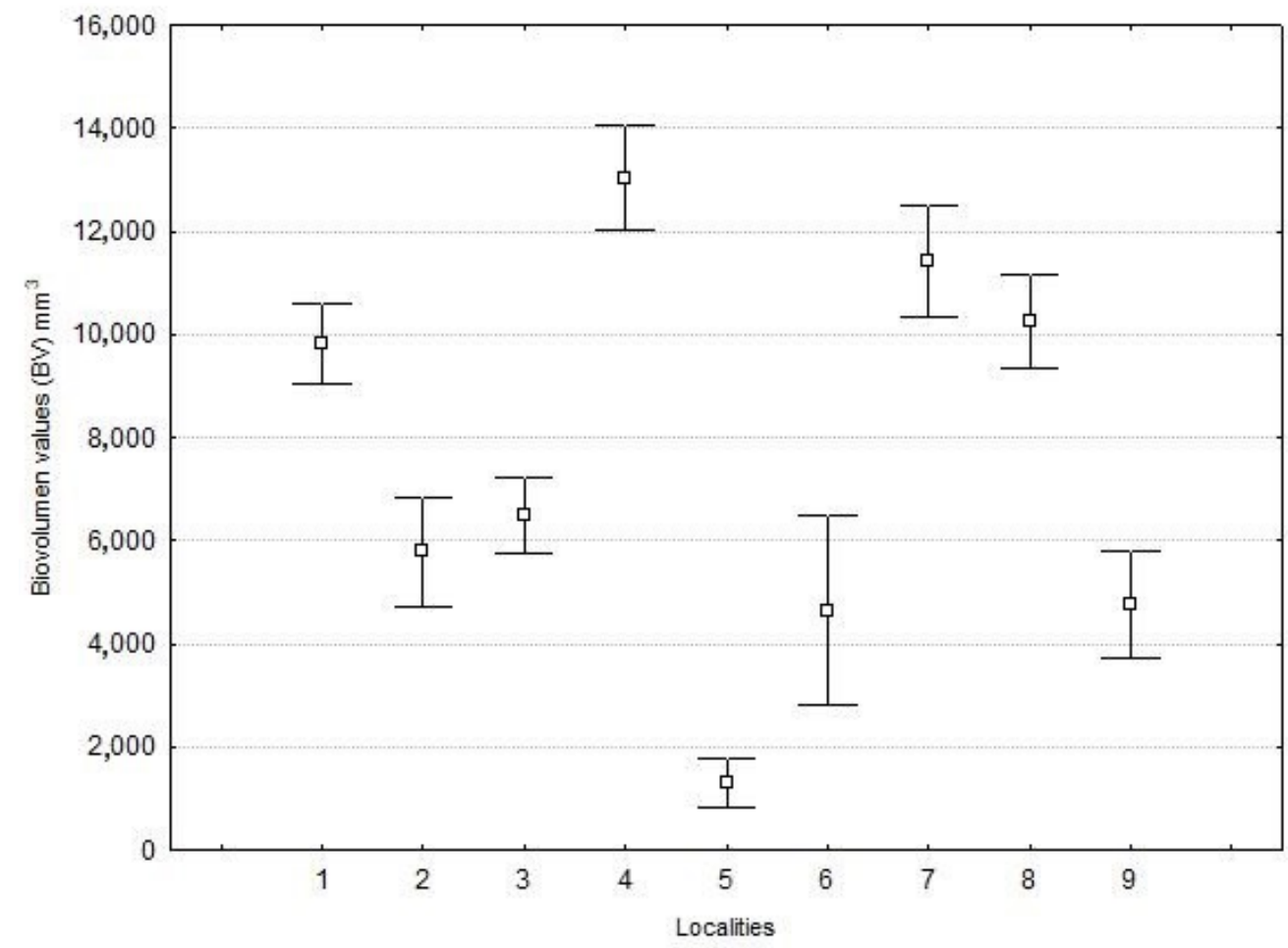

Fig. 1. Ground beetle biovolume analysis in nine study localities in central Slovakia. Data are arithmetical means; vertical lines indicate a $95 \%$ confidence interval.

Table 2. Biovolume $\left(\mathrm{mm}^{3}\right)$ of ground beetles in studied localities

\begin{tabular}{ccccc}
\hline Locality & N valid & Average biovolume & Median biovolume & SD \\
\hline Veporské vrchy Mts & & & & \\
Lichovo & 466 & 9,477 & 9,708 & 5,187 \\
Lichovo & 95 & 5,861 & 5,453 & 5,363 \\
Farkaška & 191 & 6,881 & 5,279 & 5,871 \\
Juhoslovenská kotlina Basin & & & & \\
Kúpna hora & 303 & 13,254 & 10,405 & 9,298 \\
Prievranka & 236 & 1,302 & 591 & 3,672 \\
Pažit' & 107 & 4,497 & 1,042 & 8,794 \\
Pri L'adove & 245 & 11,463 & 10,02 & 8,604 \\
Zajačie brehy & 130 & 10,244 & 10,771 & 28,381 \\
Ladovo & 100 & 4,534 & 4,102 & 4,958 \\
\hline
\end{tabular}

and we supplemented the distribution theory. Our results confirmed earlier findings (MAJZLAN and FRANTZOVÁ,1994; PORHAJÁŠOvÁ and ŠUSTEK, 2011) according to which biovolume and habitat disturbance are related. More disturbed habitats have species that are smaller and/or macropterous, while lower disturbance allows the increased presence of larger species also often brachypterous or apterous. PORHAJÁšová and Šustek
(2011) and Sono et al. (2014) pointed to the prevalence of macropterous species in habitats with an intense anthropogenic interference. Similar trends were found at 39 localities around Bratislava (ŠUSTEK, 1987), and along an urbanisation gradient near Debrecen, Hungary (LÖVEI and MAGURA, 2006). Apparently, the same trend was detectable during a recovery from heavy industrial pollution (BRAUn et al., 2004). 
Table 3. Biovolume $\mathrm{mm}^{3}$ of selected Carabidae common species for males and females

\begin{tabular}{|c|c|c|c|c|c|}
\hline Species & Sex & $\mathrm{N}$ valid & $\begin{array}{c}\text { Average } \\
\text { biovolume }\end{array}$ & $\begin{array}{c}\text { Median } \\
\text { biovolume }\end{array}$ & SD \\
\hline Abax & 오 & 74 & $4,676.38$ & $4,565.00$ & 901 \\
\hline parallelepipedus & o & 66 & $4,070.98$ & $4,052.50$ & 831 \\
\hline Carabus & 0 & 38 & $37,496.00$ & $38,157.00$ & 6,019 \\
\hline coriaceus & $\hat{\sigma}$ & 67 & $26,760.43$ & $26,856.00$ & 4,854 \\
\hline Carabus & q & 56 & $13,535.39$ & $13,689.50$ & 1,543 \\
\hline glabratus & jo & 49 & $10,881.37$ & $10,795.00$ & 1,041 \\
\hline Carabus & q & 284 & $11,317.08$ & $11,304.00$ & 31,572 \\
\hline hortensis & o & 211 & $8,428.79$ & $8,308.00$ & 1,242 \\
\hline Carabus & q & 78 & $14,783.91$ & $15,013.50$ & 2,461 \\
\hline violaceus & o & 91 & $10,594.78$ & $10,616.00$ & 1,757 \\
\hline \multirow[t]{2}{*}{ Harpalus affinis } & q & 75 & 635.32 & 635.00 & 136 \\
\hline & 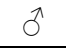 & 119 & 549.77 & 540.00 & 91 \\
\hline
\end{tabular}

\section{Conclusion}

We confirmed the lowest average Bv value presented mostly by macropterous species in the biotopes of pasture (locality 5) and nitrophilous waterside vegetation (locality 6). These localities are used as long-term agricultural land. We confirmed the highest average Bv value (mostly apterous and brachypterous species) in the biotopes which are anthropogenically least affected. We confirmed the highest average Bv value in the fallow field biotope (locality 8 ) because of a higher presence of apterous individuals; but most of them were macropterous species.

The family Carabidae is a suitable tool for the indication of the biotopes' distortion level and its ecological stability. The assessment of ecological stability is considered to be a basis for the evaluation of the current status, serving for future options for the land use. Moreover, it is a very important part of landscape planning documents in Slovakia (e.g. Development the Territorial System of Ecological Stability). Bioindication evaluation by biovolume can be used as one of the assessment approaches of environmental quality and intensity of anthropogenic impact on landscape. We have statistically confirmed that the Bv average value correlates to intensity of anthropogenic influenced on habitats.

\section{Acknowledgements}

This work was supported by the grant KEGA 025UKF4/2016: Animals in anthropogenic environment - academic text, e-learning.

\section{References}

Braun, S.D., Jones, T.H., Perner, J., 2004. Shifting average body size during regeneration after pollution - a case study using ground beetle assemblages. Ecological Entomology, 29: 543-554.

Brown, J.H., 1995. Macroecology. Chicago: University of Chicago Press. 284 p.

McGeoch, M.A., 1998. These lection, testing, and application of terrestrial insects as bioindicators. Biological Reviews, 73: 181-201.

Brygadyrenko, V.V., Reshetniak, Y.D., 2014. Morphological variability among populations of Harpalus rufipes (Coleoptera, Carabidae): What is more important - the mean values or statistical peculiarities of distribution in the population? Folia Oecologica, 41: 109-132.

HŮRKA, K., 1996. Carabidae České a Slovenské republiky [Carabidae of the Czech and Slovak Republics]. Zlín: Kabourek. 566 p.

Lövei, L.G, Sunderland, K.D., 1996. Ecology and behavior of ground beetles (Coleoptera: Carabidae). Annual Review of Entomology, 41: s. 231-256.

Lövei, L.G., Magura, T., 2006. Body size changes in ground beetle assemblages - a re-analysis of Braun et al. (2004)'s data. Ecological Entomology: 31: 411-414.

Magura, T., Tóthmérész, B., Lövei, L.G., 2006. Body size inequality of carabids along an urbanisation gradient. Basic and Applied Ecology, 7: 472-482.

MaJZlan, O., BAŤAlíK, P., 1997. Taxocenózy bystruškovitých (Coleoptera, Carabidae) ako súčast' epigeonu NPR Devínska Kobyla [Taxocoenoses of ground beetles (Coleoptera, Carabidae) in epigeon in the Protected Nature Area Devínska Kobyla hill]. Folia Faunistica Slovaca, 2: 57-60. 
Majzlan, O., Frantzová, E., 1995. Štruktúra a dynamika bystruškovitých (Coleoptera, Carabidae) epigeonu v intraviláne mesta Nitry [Structure and dynamics of ground beetles (Carabidae) populations epigeon in town of Nitra]. Rosalia, 10: 107-118.

McGeoch, M.A., 1998. The selection, testing, and application of terrestrial insects as bioindicators. Biological Reviews, 73: 181-201.

Novák, K., Balát, F., Bartoš, E., BoučeK, Z., DanIel, M., Dlabola, J., Doskočil, J., Holman, J., Jagemann, E., Kunst, M., Landa, V., Lang, J., Mařan, J., Miller, F., Nosek, J., Novák, K., Obenberger, J., Obr, S., Pelikán, J., Raušer, J., RosickÝ, B., Rusek, J., Schwarz, J., SkuhravÝ, V., Slouková, M., Šilhavý, V., Štys, P., Teyrovský, V., VondrÁČEK, K., ZAHradníK, J., ZelenskÝ, J., 1969. Metódy sbéru a preparace hmyzu [Methods of collecting and preparing insects]. Praha: Academia. $243 \mathrm{p}$.

Peters, R.H., 1983. The ecological implications of body size. Cambridge: Cambridge University Press. $148 \mathrm{p}$.

Porhajašová, J., Šustek, Z., 2011. Priestorová štruktúra spoločenstiev bezstavovcov s dôrazom na čel'ad' Carabidae v prírodnej rezervácii Žitavský luh [Spatial structure of the invertebrate communities with emphasis on the family Carabidae in the Zitavsky Luh Nature Reserve]. Nitra: Slovenská pol'nohospodárska univerzita. $77 \mathrm{p}$.

Rouabah, A., Villerd, J., Amiaud, B., Plantureux, S., LASSERre, F., 2004. Response of carabid beetles diversity and size distribution to the vegetation structure with indifferently managed field margins. Agriculture, Ecosystems \& Environment, 200: 2132 .
RuŽičKová, H., Halada, L., JedličKa, L., Kalivodová, E. (eds), 1996. Biotopy Slovenska: príručka k mapovaniu a katalóg biotopov [Biotopes of Slovakia: mapping guide and habitat catalog]. Bratislava: Ústav krajinnej ekológie SAV. 192 p.

Sonomi, S., ZaAl, K., Wataru, T., Yasuto, K., TatSuYa, S., Tamio, Y., Takahiro, F., Mohammad, R. M., Zuhair, S., KôHeI, K., KenJi, F., 2014. Ground beetle community in suburban Satoyama - A case study on wing type and body size under small scalemanagement. Journal of Asia-Pacific Entomology. 17: 775-780.

Sota, T., Yasuoki, T., Kohei, K., Masaryuki, U., RyoSUKE, I., 2000. Interspecific body size differentiation in species assemblages of the carabid subgenus Ohomopterus in Japan. Population Ecology, 42: 279-291.

StatSoft, InC., 2004. Statistica Cz. Softwarový systém na analýzu dat. Verze 7 [Statistics Cz. Software system for data analysis. Version 7]. [cit. 2016-09-10]. www.statsoft.cz

SzyszKo, J., 1983. State of Carabidae (Col.) fauna in fresh pine forest and tentative valorisation of this environment. SGGW-AG Monographs, No. 28. Warsaw: Warsaw Agricultural University Press. 124 p. Šustek, Z., 1987. Changes in body size structure of carabid community (Coleoptera, Carabidae) along an urbanisation gradient. Biologia, Bratislava, 42: 145-156.

West, G.B., Brown, J.H., Equist, J.B., 1997. A general model for the origin of allometric scaling laws in biology. Science, 276: 122-126.

Received November 23, 2016 Accepted September 25, 2017 
Appendix

Table A1. List of the Carabidae species from studied localities

\begin{tabular}{|c|c|c|c|c|c|c|c|c|c|c|}
\hline \multirow{2}{*}{ Species } & \multicolumn{9}{|c|}{ Locality } & \multirow[b]{2}{*}{ Total } \\
\hline & 1 & 2 & 3 & 4 & 5 & 6 & 7 & 8 & 9 & \\
\hline Abax ovalis (Duftschmid, 1812) & 5 & - & 1 & - & - & - & - & - & - & 6 \\
\hline Abax parallelepipedus (Piller \& Mitterpacher, 1783) & 48 & 3 & 17 & 7 & - & 19 & 14 & - & 38 & 136 \\
\hline Abax parallelus (Duftschmid, 1812) & 14 & 5 & 16 & 7 & - & 1 & 5 & - & 12 & 60 \\
\hline Agonum viduum (Panzer, 1797) & - & - & - & - & - & - & - & - & 1 & 1 \\
\hline Amara aenea (De Geer, 1774) & - & 1 & - & - & 1 & - & - & 1 & - & 3 \\
\hline Amara aulica (Panzer, 1797) & - & - & 2 & - & - & - & - & - & - & 2 \\
\hline Amara familiaris (Duftschmid,1812) & - & - & - & 1 & - & - & - & - & 1 & 2 \\
\hline Amara saphyrea Dejean, 1828 & - & - & - & - & - & - & 3 & - & 2 & 5 \\
\hline Amara similata (Gyllenhal,1810) & - & - & - & - & - & - & - & - & 1 & 1 \\
\hline Anchomenus dorsalis (Pontoppidan, 1763) & - & - & - & - & 3 & 1 & - & 2 & - & 6 \\
\hline Brachinus crepitans (Linnaeus, 1758) & - & - & - & - & 2 & - & - & 2 & - & 4 \\
\hline Calathus melanocephalus (Linnaeus, 1758) & - & - & - & - & 1 & - & - & - & - & 1 \\
\hline Calosoma Inquisitor (Linnaeus, 1758) & - & - & - & - & - & - & 1 & - & - & 1 \\
\hline Carabus cancellatus Illiger, 1798 & 3 & 6 & 27 & - & - & - & - & - & - & 36 \\
\hline Carabus convexus Fabr., 1775 & 4 & - & 8 & - & - & - & 1 & - & - & 13 \\
\hline Carabus coriaceus Linnaeus, 1758 & 9 & - & 1 & 52 & 2 & 8 & 28 & 1 & 4 & 105 \\
\hline Carabus glabratus Paykull, 1790 & 93 & 2 & 7 & - & - & - & 2 & 1 & - & 105 \\
\hline Carabus granulatus Linnaeus, 1758 & - & - & 24 & - & - & - & - & - & 7 & 31 \\
\hline Carabus hortensis Linnaeus, 1758 & 137 & - & 8 & 200 & - & - & 152 & - & - & 497 \\
\hline Carabus intricatus Linnaeus, 1761 & 10 & - & 2 & 14 & - & - & 1 & - & 5 & 32 \\
\hline Carabus nemoralis O.F.Müller, 1764 & 34 & 17 & 1 & 2 & - & - & 16 & - & - & 70 \\
\hline Carabus scheidleri Panzer, 1799 & - & 2 & - & - & 1 & 5 & - & 43 & - & 51 \\
\hline Carabus ullrichi Germar, 1824 & - & - & 38 & - & - & - & - & 24 & - & 62 \\
\hline Carabus violaceus Linnaeus, 1758 & 72 & 22 & 4 & 13 & 5 & - & 7 & 41 & 6 & 170 \\
\hline Cicindela germanica Linnaeus, 1758 & - & - & - & - & 7 & - & - & 8 & - & 15 \\
\hline Cymindis humeralis (Fourcroy, 1785) & - & - & - & 4 & - & - & 1 & - & 2 & 7 \\
\hline Cychrus caraboides (Linnaeus, 1758) & 10 & - & 1 & - & - & - & - & - & - & 11 \\
\hline Drypta dentata (Rossi, 1790) & - & - & - & - & - & - & - & 1 & - & 1 \\
\hline Elaphrus aureus P. Müller, 1821 & - & - & - & - & - & 1 & - & - & 3 & 4 \\
\hline Harpalus affinis (Schrank, 1781) & - & 5 & - & - & 187 & - & - & 2 & - & 194 \\
\hline Harpalus froelichi Sturm, 1818 & - & - & - & - & - & 7 & - & - & - & 7 \\
\hline Harpalus rubripes (Duftschmid, 1812) & - & 17 & - & - & - & - & - & - & - & 17 \\
\hline Lebia chlorocephala (Hoffm. a kol., 1803) & - & 1 & - & - & - & - & - & - & - & 1 \\
\hline Molops elatus (Fabr., 1801) & - & - & - & - & - & - & 2 & - & - & 2 \\
\hline Molops piceus (Panzer, 1793) & 26 & 4 & 1 & - & - & - & 5 & - & - & 36 \\
\hline Nebria brevicollis Fabr., 1792 & - & 2 & 7 & - & - & 2 & 2 & - & 4 & 17 \\
\hline Notiophilus biguttatus (Fabr., 1799) & - & - & - & 1 & - & - & - & - & - & 1 \\
\hline Platynus assimilis (Paykull, 1790) & - & - & 8 & - & - & 37 & - & - & 14 & 59 \\
\hline Poecilus cupreus (Linnaeus, 1758) & - & 3 & - & - & 7 & - & - & 4 & - & 14 \\
\hline Poecilus versicolor (Sturm, 1824) & - & - & - & - & 2 & - & - & - & - & 2 \\
\hline Pseudoophonus rufipes (De Geer, 1774) & - & 5 & - & - & 18 & 10 & - & - & - & 33 \\
\hline Pterostichus melanarius (Illiger, 1798) & - & - & 6 & - & - & 11 & - & - & - & 17 \\
\hline Pterostichus nigrita (Paykull, 1790) & - & - & 5 & - & - & - & - & - & - & 5 \\
\hline Pterostichus oblongopunctatus (Fabr., 1787) & 1 & - & 7 & 2 & - & 5 & 5 & - & - & 20 \\
\hline Total & 466 & 95 & 191 & 303 & 236 & 107 & 245 & 130 & 100 & 1,873 \\
\hline No. of species collected & 14 & 15 & 21 & 11 & 12 & 12 & 16 & 12 & 14 & 44 \\
\hline
\end{tabular}

